\title{
DO DIAGNÓSTICO À CONDUTA DE ENFERMAGEM: A TRAJETÓRIA DO CUIDAR NA REABILITAÇÃO DO LESADO MEDULAR.*
}

\author{
Ana Cristina Mancussi c Faro**
}

\begin{abstract}
FARO, A. C. M e Do diagnóstico à conduta de enfermagem: a trajetória do cuidar na
\end{abstract} reabilitaço do lesado medular. Rev.Esc. Enf. USP, v.29.n.2. p. 228-29. ago. 1995.

Trata-se de uma pesquisa sobre diagnósticos e condutas de enfermagem aos lesados medulares em programa de reabilitação. na qual. inicialmente, para a formulação dos diagnósticos de enfermagem, utilizou-se os registros feitos por enfermeiras da equipe de lesado medular, nos históricos de enfermagem anexados a 38 prontuários de pacientes que estavam em reabilitação no período compreendido entre 1988 e 1992 . Visou-se tambem. identificar as condutas de enfermagem mais freqüentes, bem como proceder a análise da relação diagnóstico/conduta de enfermagem. $A$ análise dos re. sultados permitiu constatar 273 diagnósticos de enfermagem distribuídos em 14 categorias diagnosticas, registradas pelas enfermeiras na Folha de Evolução. $\Lambda$ relação diagnóstico/condutas, tratada pela teste exato de Fisher. apresentou significância para o diagnóstico deficit de auto-cuidado banho e/ou higiene e obstipação percebida. Quanto a validação das condutas de enfermagem, verificou-se 76 condutas preconizadas pelos juízes, na fase $\mathrm{III}$ - Delphi, cuja ação estava voltada para orientar o paciente.

\footnotetext{
* Tese de Doutorado apresentada à Escola de Enfermagem da USP. junho. 1995.

** Professor Doutor do Departamento de Enfermagem Médico-Cirúrgica da Escola de Enfermagem da USP.
} 
FARO. A. C. M. e From diagnose to nursing intervention: the course of care on the rehabilitation of the spinal cord injuried patient. Rev.Esc. Enf. USP, v.29. n.2. p. 228-29. aug. 1995.

This research refers to the diagnosis and the nursing interventions directed to spinal cord injured patients on a rehabilitation program. At first. to the nurse diagnosis formulation the registers made by the staff nurses on the nursing assesements were used, taken from the promptuaries of 38 patients on rehabilitation during the years of 1988 to 1992 . Another objective was to identify the nursing intervention registered by those nurses at the bvolution registers. related to the most frequent nursing diagnosis, to enable the analyse of the relationship between the diagnosis and the nursing intervention. Afterwards. the Delphi techinique was used to obtain the consensus of a group of judges concerning the validation of the nursing interventions. 'The results showed 273 nursing diagnosis, grouped in 14 categories. The relationship between the diagnosis and the nursing interventions. treated by the Fisher test. was significant to the diagnosis and the nursing interventions, treated by the Fisher test. was significant to the diagnosis selfeare deficit bath and perenived dostipation. As to the nursing interventions recommend hy the judges in the Iolphi III phase. were related to the patient's orientation. 